\title{
Dietary Vitamin E Supplementation on Cholesterol and Cholesterol Oxides of Pig Meat and Cooked Ham
}

\author{
Vera Lúcia Ferreira de Souza ${ }^{1 *}$ and Rui Sérgio S. Ferreira da Silva ${ }^{2}$ \\ ${ }^{I}$ Departamento de Zootecnia; Centro de Ciências Agrárias; Universidade Estadual de Maringá (UEM); Av. \\ Colombo, 5790; 87020-900; Maringá - PR - Brasil. ${ }^{2}$ Departamento de Tecnologia de Alimentos e Medicamentos; \\ Centro de Ciências Agrárias; Universidade Estadual de Londrina (UEL); C. P. 6001; 86051-990; Londrina - PR - \\ Brasil
}

\begin{abstract}
Objective of this work was to evaluate the protective effect of vitamin E on the cooked ham. Ninety-six pigs $(L W X L$ $X(P)$, forty-eight barrows and forty-eight gilts were divided in four randomized blocks. Each block received four treatments: a control diet, diets formulated with $100 \mathrm{mg}$, with $200 \mathrm{mg}$ and with $400 \mathrm{mg}$ of vitamin E/kg diet. The average cholesterol values in cooked ham were $46.53 \pm 0.47 \mathrm{mg} / 100 \mathrm{~g}$. However, a reduction of $30 \%$ was observed in samples of supplemented diets with $400 \mathrm{mg}$ of vitamin E/kg. During shelf-life of the cooked ham was observed a reduction in the cholesterol levels, with the associated production of cholesterol oxides. The cholesterol oxides

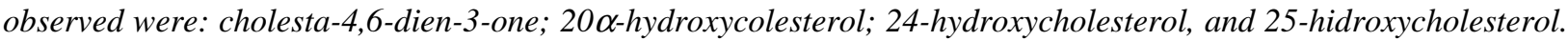
Supplementation of $200 \mathrm{mg}$ of vitamin E/kg or more maintained the cholesterol oxides values below $10 \mu \mathrm{g} / \mathrm{g}$ during the 116 days before slaughter.
\end{abstract}

Key words: Cholesta-4,6-dien-3-one; 20 $\alpha$-hydroxycolesterol; 24-hydroxycholesterol, and 25-hidroxycholesterol, liquid chromatography

\section{INTRODUCTION}

Food oxidation affects the quality and the safety of the human diet by generating compounds with biological activities that can adversely affect health. Unsaturated lipids are particularly susceptible to oxidation, and the mechanism has been throroughly studied and well documented in the literature. Lipid oxidation is responsible for the quality deterioration of muscle foods and results in the formation of lipid hydroperoxides which decompose into secondary products such as aldehydes, alcohols, ketones, and short-chain carboxylic acids (Kubow, 1990). Cholesterol is also prone to oxidation, producing a wide variety of cholestrol oxides, termed oxysterols. Cholesterol oxidation may proceed by the same mechanisms described for lipid oxidation or can be initiated by free radicals generated during the lipid oxidation (Finoccchiaro and Richardson, 1983).

Oxidized lipids and cholesterol oxides are implicated in the enhancement of atherosclerosis (Kumar and Singhal, 1991). Oxysterols are well absorbed from the diet and are transferred into cholesterol-rich lipoproteins such as very low density lipoproteins, low density lipoproteins (LDL), and chylomicrons (Guardiola et al., 1996). Oxysterols have been detected in LDL and in the atheromatous plaque (Hubbard et al., 1989). They can modify cell membrane fluidity and

\footnotetext{
${ }^{*}$ Author for correspondence
} 
permeability and inhibit cholesterol biosynthesis by suppressing hydroxy methyl glutaryl-CoA reductase activity. They also may cause cytotoxicity, angiotoxicity, mutagenicity and even carcinogenicity (Kandutsch and Chen, 1978; Smith, 1987).

The meat industry storage and processing procedures affect lipid and cholesterol oxidation. Heat treatment has negative effects on cellular structure, inactivates enzymes, releases oxygen from oxymyoglobin, creating in this way the conditions for hydrogen peroxide production. Cooking, especially at low temperatures for long time, has also the effect of releasing iron ions from heme groups. Shredding, mincing and mixing disrupt muscle structure and, in this way, increase the surface exposed to oxygen and other oxidation catalysts. Sodium chloride has pro-oxidant effects (Kanner, 1994) strengthen the effect of iron ions by moving them from prosthetic groups, so that they are available for oxidative catalysis.

One way to increase the oxidative stability of lipids and cholesterol in foods is to increase the amount of natural antioxidants such as $\alpha$ tocoppherol (vitamin E) or $\beta$-carotene in the diet. Feeding diets supplemented with vitamin E to animals like chickens, cows, and pigs resulted in vitamin accumulation in the animal muscle and better oxidative stability under prooxidative condition such as storage and cooking (Engeseth et al., 1993).

\section{MATERIALS AND METHODS}

Ninety six crossbred pigs (LW X L X P), forty eight barrows and forty eight gilts, with in average initial weight of $24 \mathrm{~kg}$ were individually penned. A randomized, complete block design with four treatments and four blocks was utilized, with initial weight serving as the blocking factor. The animal blocks were small (17 to $20 \mathrm{~kg}$ ), medium small (21 to $24 \mathrm{~kg}$ ), medium ( 25 to $28 \mathrm{~kg}$ ) and big (29 to $31 \mathrm{~kg}$ ). Within each block, pigs were randomly alloted to one of the four treatments groups, each treatment consisted of six pigs (three barrows and three gilts). The four treatments were a control diet containing no supplementary vitamin $\mathrm{E}$, diet formulated to contain $100 \mathrm{mg}$ of vitamin $\mathrm{E} / \mathrm{kg}$ diet, $200 \mathrm{mg}$ of vitamin $\mathrm{E} / \mathrm{kg}$ diet and $400 \mathrm{mg}$ of vitamin $\mathrm{E} / \mathrm{kg}$ diet. The feeding trial was divided into a growing period and a finishing period. The diets were supplemented with vitamin $\mathrm{E}$ in the form of $\alpha$-tocopherol (Rovimix 50\% ${ }^{\circledR}$, HoffmannLaRoche, Nutley, NJ - USA). Pigs were provided ad libitum access to the feed and were housed in an environmentally controlled barn. The following phases were considered in the experiment: growing phase (65 at 123 days) and finish phase (124 at 182 days), totalize 116 days before of the slaughter.

At the completion of the feeding period, pigs were weighed and feed was removed approximately 12 $\mathrm{h}$ before slaughter. The average weight of the pigs was around $110 \mathrm{~kg}$, which were slaughtered at a commercial slaughterhouse. After a $24 \mathrm{~h}$ chilling period, the biceps femoris muscles were removed from the carcass to produce the cooked hams (from the medium group and of the four treatments, 16 pigs). Before processing the cooked hams, samples of biceps femoris were taken from each ham and stored at $-20^{\circ} \mathrm{C}$ prior to analysis.

The cooked hams were produced in industrial unit. Hams were deboned and membranes, tendons, fatty tissue, and rind removed. The brine was evenly distributed over the ham muscles with a Retus Inject-O-Mat type multineedle brine injection. The cooked ham was manufactured with $64.4 \%$ of the ham without bone and $35.6 \%$ of the brine. The composition of the brine (in $\% \mathrm{v} / \mathrm{v}$ ) was salt $(4.78 \%)$, sodium eritorbate $(0.13 \%)$, monosodium glutamate $(0.30 \%)$, maltodextrin $(5.48 \%)$, phosphate $(2.44 \%)$, nitrate/nitrite $(2.14 \%)$, carageenan $(1.52 \%)$, protein isolate $(4.48 \%)$, sugar $(2.39 \%)$, cochineal dye $(0.03 \%)$ and water $(76.31 \%)$. For distribution of the curing ingredients throughout the entire product, each ham was tumbled for $40 \mathrm{~min}$, and stored for $12 \mathrm{~h}$ at $2^{\circ} \mathrm{C}$. The following day, the hams were tumbled again for $40 \mathrm{~min}$, stuffed into polyethelene film and vacuum pressed, and heated in bath at $62^{\circ} \mathrm{C}$ for $30 \mathrm{~min}$. The cooked hams were stored at $5^{\circ} \mathrm{C}$ for analysis for two months.

Slices of biceps femoris were thawed and homogenated with blender. The extration and determination of total lipids were undertaken according to the method of Folch et al. (1957). Cholesterol oxides, cholesterol and total lipids were determined from the same extract of meat and cooked ham. Cholesterol and cholesterol oxides were determined simultaneously by high performance liquid chromatography according to method of Sander et al. (1989), modified by Baggio and Bragagnolo (2000). The following stages were carried out: lipid extraction, cold saponification and extration of unsaponificable 
material. A Schimadzu Liquid Chromatograph equipped with binary system LAD 10, M10A detector and autosampler with a $20 \mu \mathrm{L}$ loop was used to apply the samples. Separations were achieved with a normal-phase $5 \mu \mathrm{m}$ Nova Pack CNHP column (300 x $3.9 \mathrm{~mm}$ i.d.), and Hypersil BDSCN with guard column $(7.5 \times 4.6 \mathrm{~mm}, 5 \mu \mathrm{m})$. The eluent flow rate through the chromatographic column was $1.0 \mathrm{~mL} / \mathrm{min}$. The column was equilibrated with a mobile phase consisting of $96 \%$ hexane and $4 \%$ isopropanol ( $\mathrm{vol} / \mathrm{vol})$ and at $32^{\circ} \mathrm{C}$ of the temperature. The method was validated in terms of recovery, repeatability, detection limit and quantification limit (De Bruin et al., 1998). The cholesterol and cholesterol oxides were identified by the retention times compared with those of standards, spiking and the UV spectra (200 to $400 \mathrm{~nm}$ ), helped by Class-LC 10 software. The peak purity was ascertained by the UV spectra and confirmed by GC-MS. The identity of separated molecules was confirmed with a Hewlett Packard chromatograph 6890 equipped with a mass selector MSHP 5973. The interface temperature was $320^{\circ} \mathrm{C}$ and electron impact ionisation at an energy of $70 \mathrm{eV}$. Chromatography was run with a fused silica capillary column $(30 \times 0.255 \mathrm{~mm}, 0.25 \mu \mathrm{m})$ with helium as carrier gas at a pressure of $10 \mathrm{psi}$ and flow rate of $0.7 \mathrm{~mL} / \mathrm{min}$. The interface temperature was $320^{\circ} \mathrm{C}$ and electron impact ionisation at an energy of $70 \mathrm{eV}$. Injector line temperature was $290^{\circ} \mathrm{C}$ and column temperature was programmed began at $110^{\circ} \mathrm{C} / 2 \mathrm{~min} ; 235^{\circ} \mathrm{C} / 5 \mathrm{~min}$ at $40^{\circ} \mathrm{C} / \mathrm{min}$; $310^{\circ} \mathrm{C} / 5 \mathrm{~min}$ at $1^{\circ} \mathrm{C} / \mathrm{min}$. The cholesterol (MerckGerman) and oxides cholesterol (Sigma Chemical Company and Steraloids Inc.-USA) standards and the samples were derivatized according Schamrr et al. (1996). The cholesterol and cholesterol oxides of ham and cooked ham were analysed in the same way descripted above at 0,30 and 60 days of storage.

The statistical signicance of the difference between the cholesterol leves in biceps femoris muscle and cooked ham was determinad by ANOVA. Significance of the difference between means was determined by Tukey test. Statistical analysis of the cholesterol and cholesterol oxides from cooked ham between treatments and sex during 60 days period $(0,30$ and 60 days) was tested in a split-plot design (Gomes, 1985). Singledegree-of-freedom, orthogonal contrasts were done when significant $(P<0.05)$ effects of treatments were observed. All data were analyzed using the General Linear Model procedure of SAS (1999). Two barrows and two gilts by treatments and by pens was drawing lots, at random, represented the replication. The tests of the multiple comparision were performed by Tukey $(P$ $<0.05)$. The panel for analysis of variavel desing was:

\begin{tabular}{lc}
\hline \multicolumn{1}{c}{ Source of Variation } & Degree of Freedom \\
\hline Treatments (T) & $(4-1)=3$ \\
Sex (S) & $(2-1)=1$ \\
T x S(a) & $(3 \times 1)=3$ \\
Time (t) & $(3-1)=2$ \\
T x t & $(3 \times 2)=6$ \\
Residue (b) & $(47-15)=32$ \\
\hline Total & $(48-1)=47$ \\
\hline
\end{tabular}

\section{RESULTS AND DISCUSSION}

Table 1 shows the average cholesterol contents in samples of ham, according to ANOVA results of Table 2. As the vitamin E levels in the diet were increased, a reduction in cholesterol contents occured approximately, reaching 30\% in the levels of supplementation of $400 \mathrm{mg}$ of vitamin $\mathrm{E} / \mathrm{kg}$ diet. Between the sexes significant difference were observed $(P<0.05)$, with the barrows samples presenting average of $41.46 \pm 0.42 \mathrm{mg} / 100 \mathrm{~g}$, superior to the gilts of $38.16 \pm 0.40 \mu \mathrm{g} / 100 \mathrm{~g}$.

There is not information on the reduction in the cholesterol levels in swines with the vitamin E ingestion in literature. However, DiéberRotheneder et al. (1991) had observed a reduction in the lipoprotein levels of low density (LDL) in human plasma, when they received vitamin E via oral. In experiment in vitro, Shige et al. (1998) had observed a reduction in LDL contents, in culture of cells J774 (macrophages), that presented concentration of $50 \mu \mathrm{mol}$ of vitamin E. As LDL is part of the cholesterol, its reduction will imply in a reduction in total cholesterol contents, as observed in the present research.

During the cooked ham processing a significant reduction $(P<0.05)$ in cholesterol contents occurred, in all the treatments and sexes (Table 3 ). The reduction in cholesterol contents occurred probably due to the mass increase of the ham with the injection of the cure solution.

Table 4 shows the ANOVA of cholesterol contents of cooked ham, during the period of storage, indicating significant difference $(P<0.05)$ in all the analyzed causes of variation. During this 
period of storage, a decrease in cholesterol contents occurred (Fig. 1) in cooked ham, but more evident in treatment 1 (control), reducing to at the same time that increase the levels of vitamin $\mathrm{E}$ in the diet. The treatment 4 remained practically constant with supplementation levels of $400 \mathrm{mg}$ of vitamin $\mathrm{E} / \mathrm{kg}$ diet. An important observed correlation $(\mathrm{r}=0.70)$ was between cholesterol contents of cooked ham (Y) and the treatments (x), with the linear regression: $\mathrm{Y}=38.495-0.022 \mathrm{x}$.

Table 1 - Effect of the Different Treatments on the Levels Cholesterol of $\mathrm{Ham}^{a}$

\begin{tabular}{cc}
\hline Treatment (mg of vitamin E/kg diet) & Cholesterol levels (mg/100g) \\
\hline 11 & $46.53 \pm 0.47^{\mathrm{a}}$ \\
100 & $41.65 \pm 0.42^{\mathrm{b}}$ \\
200 & $37.73 \pm 0.38^{\mathrm{c}}$ \\
400 & $33.33 \pm 0.33^{\mathrm{d}}$ \\
\hline
\end{tabular}

${ }^{a}$ Means obtained among the three repetitions and the sexes.

Different letters in the same column are significantly different $(\mathrm{P} \leq 0.05)$.

Table 2 - Analysis of Variance (ANOVA) for Ham Cholesterol Levels.

\begin{tabular}{l|r|r|r|r|r}
\hline \multicolumn{1}{c}{ SV } & DF & \multicolumn{1}{c|}{ SS } & MS & \multicolumn{1}{c}{ F } & P \\
\hline Treatment & 3 & 379.28 & 126.42 & 786.08 & 0.0001 \\
Sex & 1 & 43.62 & 43.62 & 271.26 & 0.0001 \\
Residue(a) & 11 & 1.77 & 0.16 & & \\
Total & 15 & 424.67 & & & \\
$\mathrm{R}^{2}=0.9958$ & \multicolumn{3}{c}{$\mathrm{CV}(\%)=1.007$} &
\end{tabular}

Table 3 - Treatment, Sex and Processing Effects on Ham Cholesterol Levels and Cooked Ham ${ }^{a}$

\begin{tabular}{|c|c|c|c|c|}
\hline \multirow{2}{*}{$\begin{array}{c}\text { Treatment } \\
\text { (mg vit. E/kg diet) }\end{array}$} & \multirow{2}{*}{$\operatorname{Sex}^{b}$} & \multicolumn{2}{|c|}{ Cholesterol levels (mg/100 g ) } & \multirow{2}{*}{$\mathrm{CV}(\%)^{\mathrm{c}}$} \\
\hline & & Ham & Cooked ham & \\
\hline \multirow[t]{2}{*}{11} & $\mathrm{M}$ & $48.61^{\mathrm{a}}$ & $45.05^{\mathrm{b}}$ & 1.78 \\
\hline & $\mathrm{F}$ & $44.45^{\mathrm{a}}$ & $40.86^{\mathrm{b}}$ & 1.51 \\
\hline \multirow[t]{2}{*}{100} & M & $43.03^{\mathrm{a}}$ & $41.38^{\mathrm{b}}$ & 1.82 \\
\hline & $\mathrm{F}$ & $40.26^{\mathrm{a}}$ & $38.27^{\mathrm{b}}$ & 1.64 \\
\hline \multirow[t]{2}{*}{200} & M & $39.30^{\mathrm{a}}$ & $37.00^{\mathrm{b}}$ & 2.04 \\
\hline & $\mathrm{F}$ & $36.16^{\mathrm{a}}$ & $33.83^{\mathrm{b}}$ & 2.32 \\
\hline \multirow[t]{2}{*}{400} & M & $34.89^{\mathrm{a}}$ & $31.45^{\mathrm{b}}$ & 2.17 \\
\hline & $\mathrm{F}$ & $31.77^{\mathrm{a}}$ & $28.75^{\mathrm{b}}$ & 2.54 \\
\hline
\end{tabular}

${ }^{a}$ Means obtained among three repetitions.

${ }^{b} \mathrm{M}=$ barrow $\quad \mathrm{F}=$ gilts

${ }^{c} \mathrm{CV}(\%)=$ Coeficient of variation

Different letters in the same row are significantly diferent $(P<0.05)$.

Table 4 - Analysis of Variance (ANOVA) for Cooked Ham Levels, during the Shelf-Life (60 days)

\begin{tabular}{l|r|r|r|r|r}
\hline \multicolumn{1}{c}{ SV } & DF & \multicolumn{1}{c}{ SS } & \multicolumn{1}{c}{ MS } & \multicolumn{1}{c}{ F } & P \\
\hline Treatments & 3 & 500.58 & 166.86 & 1376.39 & 0.0001 \\
Sex & 1 & 109.38 & 109.38 & 902.29 & 0.0001 \\
Treat x Sex(a) & 3 & 7.21 & 2.40 & 19.82 & 0.001 \\
Time & 2 & 263.96 & 131.98 & 1088.69 & 0.0001 \\
Treat x Time & 6 & 244.46 & 40.74 & 336.08 & 0.0001 \\
Residue(b) & 32 & 3.88 & 0.12 & & \\
Total & 47 & $1,129.47$ & & & \\
$\mathrm{R}^{2}=0.9965$ & $\mathrm{CV}(\%)=1.004$ &
\end{tabular}


The reduction in cholesterol contents during the storage of cooked ham (Fig. 1), clearly observed in treatments 1 and 2, was followed by the increase in cholesterol oxide contents (Fig. 2), confirming their origin. At zero time storage cholesterol oxides was not observed in the samples of cooked ham (Fig. 2). Park and Addis (1987) and Monahan et al. (1992) also found similar results.

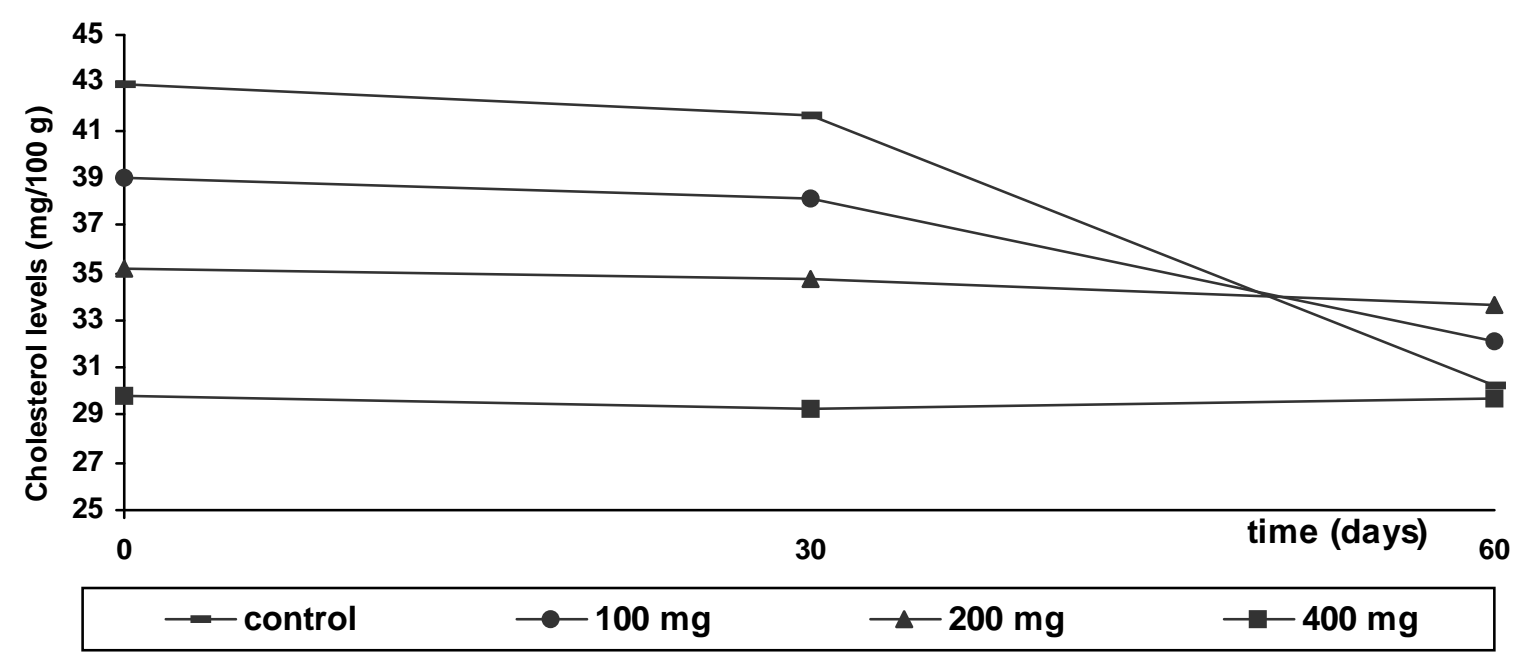

Figure 1 - Effect on the Cholesterol Levels of Cooked Ham, during the Shelf-Life ${ }^{a}$.

${ }^{a}$ Means obtained on true repetitions and two sexes (barrows and gilts).

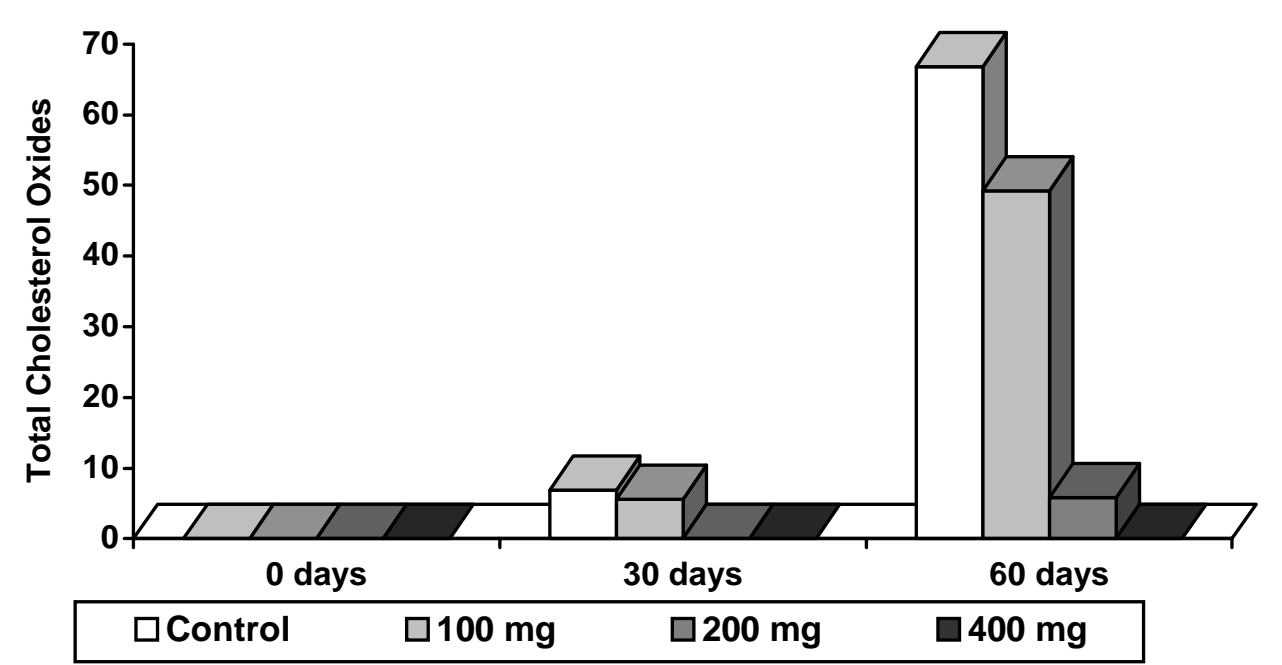

Figure 2 - Effect on the Total of Cholesterol Oxides $(\mu \mathrm{g} / \mathrm{g})$ from Cooked Ham, during the Shelf-Life ${ }^{a}$.

${ }^{a}$ Means obtained on true repetions and two sexes (barrows and gilts)

During the 60 days storage, a substantial increase in the cholesterol oxide total in the samples of cooked ham of treatments 1 and 2 occurred (Fig. 2). This was mainly due to the presence of 24-hydroxycholesterol, in concentrations varying $34.15 \pm 1.48$ to $60.11 \pm 2.61 \mu \mathrm{g} / \mathrm{g}$. Also, $25-$ hydroxycholesterol was found in the samples of treatments 1 and 2, although in small concentrations, varying from $4.18 \pm 0.13$ to $6.33 \pm$ $0.19 \mu \mathrm{g} / \mathrm{g}$. In the samples of treatment 3 , cholesta4,6-dien-3-ona were found in the concentrations varying from $2.66 \pm 0.07$ to $3.22 \pm 0.08 \mu \mathrm{g} / \mathrm{g}$, and 
$20 \alpha$-hydroxycholesterol in the concentrations varying from $2.60 \pm 0.08$ to $2.99 \pm 0.09 \mu \mathrm{g} / \mathrm{g}$, presenting a similar behavior to treatment 2 with 30 days of storage. No cholesterol oxide was observed (Fig. 2) in the treatment 4 samples.

In the samples of ham and cooked ham at time zero (initial) storage, cholesterol oxides was not detected in the treatments or sex (Fig. 2). With 30 days of storage cholesterol oxides was found in the samples of cooked ham (treatments 1 and 2). The cholesterol oxides were cholesta-4,6-dien-3-ona (dieno) in concentrations varying from $2.56 \pm 0.08$ to $4.18 \pm 0.11 \mu \mathrm{g} / \mathrm{g}$; and $20 \alpha$-hydro-cholesterol $(20 \mathrm{~A}-\mathrm{OH})$, in concentrations varying from $2.22 \pm$ 0.07 to $3.15 \pm 0.11 \mu \mathrm{g} / \mathrm{g}$ (Fig. 2). The main cholesterol oxides found in foods are 25hydroxycholesterol, cholestan-3 $\beta-\alpha-6 \beta$-triol, $5,6 \alpha-$ epoxycholesterol, 5,63-epoxycholesterol, 7-ketocholesterol, and cholesta-4,6-dien-3ona (Finocchiaro and Richardson, 1983). Sander et al. (1989), analyzing samples of lyophilized turkey, found the following cholesterol oxides: 5,6 $\beta$ epoxycholesterol $(8 \mu \mathrm{g} / \mathrm{g}), 5,6 \alpha$-epoxycholesterol $(21 \mu \mathrm{g} / \mathrm{g}), 7 \beta$-hydroxycholesterol $(18 \mu \mathrm{g} / \mathrm{g})$ and 7 ketocholesterol $(20 \mu \mathrm{g} / \mathrm{g})$. In storage bovine meat at $10^{\circ} \mathrm{C}$, during 30,60 and 90 days, $11.91,12.26$ and $13.88 \mu \mathrm{g} / \mathrm{g}$ of 7-ketocholesterol, were found respectively (Penazzi et al., 1995). Engeseth et al. (1993), varying the temperature of storage of the veal meat, had observed the following concentrations for 7-ketocholesterol: 10.44 and $12.29 \mu \mathrm{g} / \mathrm{g}$ at $4^{\circ} \mathrm{C} ; 13.00$ and $15.60 \mu \mathrm{g} / \mathrm{g}$ at $10^{\circ} \mathrm{C}$; on the third and sixth day, respectively.

In swine meat $7 \alpha$-hydroxycholesterol, $7 \beta$ hydroxycholesterol, $\alpha$-epoxycholesterol, $\quad \beta$ epoxycholesterol and 7-ketocholesterol, in concentrations varying from 0.55 to $3.85 \mu \mathrm{g} / \mathrm{g}$; and in salami samples: $7 \alpha$-hydroxycholesterol; $7 \beta$ hydroxylesterol; $20 \alpha$-hydroxycholesterol, $\alpha$ epoxycholesterol; $\beta$-epoxycholesterol and 7ketocholesterol; in concentrations varying of 0.38 to $2.21 \mu \mathrm{g} / \mathrm{g}$ were found (Lake and Scholes, 1997). Rowe et al. (1997) observed average $47.39 \pm 3.24$ $\mu \mathrm{g} / 100 \mathrm{~g}$ cholesterol content in swine ham, which were very close levels to those observed in the present work, despite using different methodology of analysis and cooking of samples in boiling fat. On the other hand, they observed superior average for cooked ham of $111.07 \pm 28.02 \mu \mathrm{g} / 100 \mathrm{~g}$. As the cooked ham samples were obtained randomly in the ordinary market, this difference was predictable due to probable use of different types of fat, not only in the qualitative but also in the quantitative aspect during processing.

Novelli et al. (1998), analyzing salami Milano and mortadella samples observed great variation in cholesterol contents and cholesterol oxides. In salami Milano samples, the cholesterol contents varied from 34.29 to $119.01 \mu \mathrm{g} / 100 \mathrm{~g}$, and in the mortadella from 52.11 to $138.14 \mu \mathrm{g} / 100 \mathrm{~g}$. The cholesterol oxides found in the samples were $7 \beta$ hydroxycholesterol, 5,6 $\alpha$-epoxycholesterol, 7ketocholesterol and 25-hydroxycholesterol, with values varying from 0.42 to $15.82 \mu \mathrm{g} / \mathrm{g}$.

$7 \alpha$-hydroxycholesterol, $7 \beta$-hydroxycholesterol and 7 -ketocholesterol were not found in ham and cooked ham samples analyzed in the present work. This apparently contradicted the hypothesis of Teng et al. (1973) that the first oxides formed by the cholesterol auto-oxidation were $7 \alpha, 7 \beta-$ hydroxycholesterol and 7-ketocholesterol. Korahani et al. (1982) suggested that the presence of fatty acid such as C18:0 and C18:1 inhibited the cholesterol oxidation. Nawar et al. (1991) observed that during the heating of cholesterol at $180{ }^{\circ} \mathrm{C}$ for $1 \mathrm{~h}$ in lysine presence reduced the concentration of 7-ketocholesterol from 9.2 to 0.6 $\mu \mathrm{g} / \mathrm{g}(93.5 \%)$, decreased the formation of $7 \alpha$ and $7 \beta$-hydroxycholesterol and increased concentration of cholesta-4,6-dien-3-ona from 0.6 to $4.2 \mu \mathrm{g} / \mathrm{g}(85.7 \%)$, when compared to the heating with no lysine.

The diet supplied to swines was rich in lysine, which was incorporated to the muscle, and was not destroyed during the cooked ham processing. Probably that was the cause for not finding 7ketocholesterol and $7 \alpha, 7 \beta$-hydroxycholesterol, which were below the detection limit, and cholesta-4,6-dien-3-ona was identified.

The cholesterol oxide cholesta-4,6-dien-3-ona has been observed in different food products, such as butter (Roderbourg and Kudzl-Savoie, 1979): bovine and swine fat (Ryan et al., 1981; Chen et al., 1994), eggs (Penock et al., 1962), milk powder (Flanagan et al., 1975; Chan et al., 1993), bovine meat (Vajdi and Nawar, 1979; Hwang and Maerker, 1993), swine meat (Hwang and Maerker, 1993), and fish (Adachi et al., 1996), with values varying from 0.36 to $5.9 \mu \mathrm{g} / \mathrm{g}$, depending on the processing and storage. The cholesterol oxide 20 $\alpha$-hydroxycholesterol was reported in butter and eggs (Pie et al., 1991), swine and bovine meat (Pie et al., 1991; Schmarr et al., 1996), salami and parmesan cheese (Schmarr et al., 1996) in 
concentrations varying from 0.14 to $10.88 \mu \mathrm{g} / \mathrm{g}$. 25-hydroxycholesterol is considered as the most cytotoxic of cholesterol oxides, therefore, it inhibits the activity of 3-hydroxy-3methylglutanyl-coenzyme A-reductase (HMGCoA), leading to the reduction of the endogenous synthesis of the cholesterol (Addis, 1989; Kubow, 1990; Kumar and Singhal, 1991). It was found in swine meat and poultry (Finocchiaro and Richardson, 1983), in Milano salami and mortadella (Novelli et al., 1998) in concentrations varying from 0.42 to $15.82 \mu \mathrm{g} / \mathrm{g}$. The cholesterol and 24-hydroxycholesterol were confirmed in the GC-MS, but it was not possible to confirm about the other cholesterol oxides.

References on 24-hydroxycholesterol in foods have not been found, however, its presence in cooked ham samples were confirmed in HPLC and GC-MS, with $97 \%$ probability. On the other hand, the confirmation of the dieno, the $20 \alpha-\mathrm{OH}$ and the $25-\mathrm{OH}$ in the GC-MS was not possible, probably due to the low concentrations and mainly to inappropriate chromatographic conditions employed.

The references on GC-MS presented more convenient chromatographic conditions, as of injection of the sample at $30^{\circ} \mathrm{C}$, kept during 1 minute and rising up to $140-280{ }^{\circ} \mathrm{C}$ at a rate of $10^{\circ} \mathrm{C} /$ minute (Chen et al., 1994). Less polar columns such as the DB-1 (Addis, 1986; Nawar et al., 1991; Monahan et al., 1992; Chan et al., 1993; Salin et al., 1995), the DB-5 (Hwang and Maerker, 1993; Schmarr et al., 1996; Lake and Scholes, 1997), or the CB-5 (Pie et al., 1991), in place of the HP-SMS used here were employed.

Considering all the stages to determine the cholesterol and its oxides, the following averages were observed: recovery $90.96 \%$; detection limit $0.56 \mu \mathrm{g} / \mathrm{g}$; quantification limit $1.86 \mu \mathrm{g} / \mathrm{g}$ and coefficient of variation $0.64 \%$ (probability level of 94 to $97 \%$ ). Anyway, $90.96 \%$ recovery in the present work was superior to $78 \%$ cited by Baggio and Bragagnolo (2000), and close to $93 \%$ observed by Nielsen et al. (1995). The detection limit $(0.56 \mu \mathrm{g} / \mathrm{g})$ was close to the $0.38 \mu \mathrm{g} / \mathrm{g}$ observed by Csallany et al. (1989) and Baggio and Bragagnolo (2000), but inferior to the $1.00 \mu \mathrm{g} / \mathrm{g}$ described by Rose-Salin et al. (1995). The precision of the analytical method was very good, presenting a $0.64 \%$ coefficient of variation (CV). Rose-Salin et al. (1995) considered good precision, when $\mathrm{CV}$ present values between 0.5 and $1.2 \%$.

\section{ACKNOWLEDGMENT}

Research supported in part by Roche - Importer of Chemist and Pharmacist Roche Products S.A. Hoffmann - La Roche Inc. Nertley, N.J. 07110 USA; COPAGRIL, Marechal Cândido Rondon, Paraná - Brasil; FRIMESA-SUDCOOP, Medianeira, Paraná - Brasil and ITAL - Institute of Food Technology, Campinas, São Paulo Brasil.

\section{RESUMO}

O objetivo deste trabalho foi avaliar o efeito protetor da vitamina $\mathrm{E}$ no presunto cozido. Noventa e seis suínos (LW X L X P), 48 machos castrados e 48 fêmeas foram divididos aleatoriamente em 4 blocos. Cada bloco recebeu 4 tratamentos: dieta controle, dietas formuladas com $100 \mathrm{mg}$, com $200 \mathrm{mg}$ e com $400 \mathrm{mg}$ de vitamina $\mathrm{E} / \mathrm{kg}$ de ração. O período de fornecimento da dieta foi de 116 dias antes do abate, quando os suínos atingiram uma média de peso de $110 \mathrm{~kg}$. O presunto cozido foi produzido em um frigorífico, e estocado a $5,0 \pm 0,2^{\circ} \mathrm{C}$ para as análises químicas. Análise de colesterol e óxidos de colesterol foram feitas em amostras de presunto cozido com $0,30 \mathrm{e}$ 60 dias de armazenamento. O colesterol e os óxidos de colesterol foram determinados por cromatografia líquida. A média para os níveis de colesterol foi de 46,53 $\pm 0,47 \mathrm{mg} / 100 \mathrm{~g}$. Entretanto, foi observada uma redução de $30 \%$ nos níveis de colesterol das amostras que receberam suplementação de $400 \mathrm{mg}$ de vitamina $\mathrm{E} / \mathrm{kg}$. Durante o armazenamento do presunto cozido foi observado uma redução nos níveis de colesterol, associada a um aumento nos níveis de óxido de colesterol. Os óxidos de colesterol observados foram: cholesta-4,6-dien-3-one; 20 $\alpha$ hydroxycolesterol; 24-hydroxycholesterol e 25hidroxycholesterol. Níveis de suplementação de $200 \mathrm{mg}$ de vitamina $\mathrm{E} / \mathrm{kg}$ ou mais, fornecidos durante 116 dias antes do abate, mantiveram os teores de óxidos de colesterol abaixo de $10 \mu \mathrm{g} / \mathrm{g}$. 


\section{REFERENCES}

Adachi, J.; Hojo, K.; Naito, T. and Tatsumo, Y (1996), Oxysterols Found in Opacified Cornea of Fish, Lipids, 31 : (10), 1039-1043.

Addis, P. B. (1986), Occurrence of Lipid Oxidation Products in Foods, Food. Chem. Toxic., 24, 1021.

Baggio, S. and Bragagnolo, N. (2000) Validação da Metodologia para Determinação Simultânea, por CLAE, de Colesterol e Óxidos de Colesterol em Carne de Peru. In: Congresso Brasileiro de Qualidade, 17., Fortaleza. Anais ... Fortaleza-CE.

Chan, S. H.; Gray, J. I. and Gomaa, E. A. (1993), Cholesteol Oxidation in Whole Milk Powders as Influenced by Processing and Packaging, Food Chem., 47, 321-328.

Chen, Y. C.; Chiu, C. P. and Chen, B. H. (1994), Determination of Cholesterol Oxides in Heated Lard by Liquid Chromatography, Food Chem., 50, 53-58.

Csallany, A. S.; Kindom, S. E.; Addis, P. B. and Lee, J. (1989), HPLC Method for Quantitation of Cholesterol and Four of its Major Oxidation Products in Muscle and Liver Tissues, Lipidsi, 24, 645.

De Bruin, L. S.; Josephy, P. D. and Pawlisyn, J. B. (1998), Solid Phase Microextraction of Monocyclic Aromatic Amines from Biological Fluids, Anal. Chem., 70 :(9), 1986-92.

Dieber-Rotheneder, M.; Puhl, H.; Waeg, G.; Striegl, G. and Esterbauer, H. (1991), Effect of Oral Supplementation with D- $\alpha$-Tocopherol on the Vitamin E Content of Human Low Density Lipoproteins and Resistance to Oxidation, J. Lipid Res., 32, 1325-1332.

Engeseth, N. J.; Gray, J. I.; Booren, A. M. and Asghar, A. (1993), Improved Oxidative Stability of Veal Lipids and Cholesterol through Dietary Vitamin E Suplementation, Meat Sci., 35, 1-15.

Finocchiaro, E. J. and Richardson, J. (1983), Sterol Oxides in Foodstuffs: a Rewiew, J. Food Prot., 46, 917.

Flanagan, V. P. A.; Ferritti, D. P. and Ruth, J. M. (1975), Characterization of two Steroidal Ketones and two Isoprenoid Alcohols in Dairy Products, $J$. Lipid Res., 16, 97-101.

Folch, J.; Less, M. and Stanley, S. A. (1957), A Simple Method for the Isolation and Purification of Total Lipids from Animal Tissues, J. Biol. Chem., 226, 497.

Guardiola, F.; Codony, R.; Addis, P. B.; Rafecas, M. and Boatella, J. (1996), Biological Effects of Oxysterols; Current Status, Food Chem. Toxic., 34, 193-211.

Gomes, F. G. (1985), Curso de Estatística Experimental. $11^{\text {th }}$ ed. Piracicaba: Livraria Nobel. pp. 151-174.

Hubbard, R. W.; Ono, Y. and Sanchez, A. (1989), Atherogenic Effects Oxidezed Products of Cholesterol, Progr. Food Nutr. Sci., 13, 17.
Hwang, K. T. and Maerker, G. (1993), Determination of-6-Ketocholestanol in Unirradiated and Irradiated Chicken Meats, J. Am. Oil Chem. Soc., 70 :(8), 789-792.

Kandutsch, A. A. and Chen, H. H. (1978), Inibition of Cholesterol Synthesis by Oxigenated Sterols, Lipids, 13, 704.

Kanner, J. (1994), Oxidative Processes in Meat and Meat Products: Quality Implications, Meat Sci., 36, 169-189.

Korahani; V.; Bascoul, J. and Crastes De Paulet, A. (1982), Autoxidation of Cholesterol Fatty Acid Esters Insolid State and Aqueous Dispersion, Lipids, 17 : (10), 703-708.

Kubow, S. (1990), Toxicity of Dietary Lipid Peroxidation Products, Trends in Food Science and Technology, 1, 67.

Kumar, N. and Singhal, O. P. (1991), Cholesterol Oxides and Atherosclerosis: Review. J. Sci. Food and Agric., 55, 497.

Lake, R. J. and Scholes, P. (1997), Consumption of Cholesterol Oxides from Fast Foods Fried in Beef Fat in New Zealand, J. Am. Oil Chem. Soc., 74, 9.

Monhan, F. J.; Gray, J. I.; Booren, A. M.; Miller, E. R.; Buckley, D. J.; Morrissey, P. A. and Gomaa, E. A. (1992), Influence of Dietary Treatment of Lipid and Cholesterol Oxidation in Pork, J. Agric. Food Chem., 40, 1310-1315.

Nawar, W. W.; Kim, S. K.; Li, Y. J. and Vajdim, M. (1991), Measurement of Oxidatine Interactions of Cholesterol, J. Am. Oil Chem. Soc., 68 : (7), 496-498.

Nielsen, J. H.; Olsen, C. E.; Duedahl, C. and Skibsted, L. H. (1995), Isolation and Quantitation of Cholesterol Oxides in Dairy Products by Selected Ion Monitoring Mass Spectrometry, J. Dairy Res., 62, 101.

Novelli, E.; Zanardi, E.; Ghiretti, G. P.; Campanini, G.; Dazzi, G.; Madarena, G. and Chizzolini, R. (1998), Lipid and Cholesterol Oxidation in Frozen Stored Pork, Salame Milano and Mortadella, Meat Sci., 48 : (1/2), 29-40.

Park, S. W. and Addis, P. B. (1987), Cholesterol Oxidation Products in Some Muscle Foods, J. Food Sci., 52, 1500-1503.

Penazzi, G.; Caboni, M. F.; Zunin, P.; Evangelist, F.; Tiscornia, E.; Toschi, T. G. and Lercker, G. (1995), Routine High-Performance Liquid Chromatografhic Determination of Free 7-Ketocholesterol in some Foods by two Different Analytical Methods, J. Am. Oil Chem. Soc., 72, 1523.

Penock, J. F.; Neiss, G. and Mahler, H. R. (1962), Biochemical Studies on the Developing Avian Embryo, Biochem. J., 85, 530-537.

Pie. J. E.; Spahis, K. and Seillan, C. (1991), Cholesterol Oxidation in Meat Product during Cooking and Frozen Storage, J. Agric. Food Chem., 39, 250-254.

Roderbourg, H. and Kudzl-Savoie, S. (1979), The Hydrocarbons of-Anhydrous Butterfat: Influence of Technological Treatments, J. Am. Oil Chem. Soc., 56, 485-488. 
Rosel-Sallin, C.; Huggett, A. C.; Bosset, J. O.; Tabacchi, R. and Fay, L. B. (1995), Quantification of Cholesterol Oxidation Products in Milk Powders using $\left[{ }^{2} \mathrm{H}_{7}\right]$ Choleterol to Monitor Cholesterol Autoxidation Artifacts, J. Agric. Chem., 43, 935.

Rowe, A.; Bertoni, S. A.; Pereira, P. L.; Matsuhita, M. and Souza, N. E. (1997), Colesterol em Carnes Bovinas, Suínas, Frangos e Derivados de Carnes Comercializados em Maringá, Paraná, Brasil, Archivos Latinoamericanos de Nutricion, 47 :(3), 282-284.

Ryan, T. C.; Gray, J. I. and Morton, I. D. (1981), Oxidation of Cholesterol in Heated Tallow, J. Sci. Food Agric., 32, 305-308.

Sallin, C. R.; Huggett, A. C.; Bosset, J.; Tabacchi, R. and Fay, L. B. (1995), Quantification of Cholesterol Oxidation Products in Milk Powders using $\left[{ }^{2} \mathrm{H}_{7}\right]$ Chosleterol to Monitor Choslesterol Autoxidation Artifacts, J. Agric. Chem., 43, 93.

Sander, B. D.; Addis, P. B.; Park, S. W. and Smith, D. E. (1989), Quantification of Cholesterol Oxidation Products in a Variety of Foods, J. Food Prot., 52, 109.

SAS (1999), Statistical Analyses System, Instituto SAS, Cary, NC, USA.
Schmarr, H. G.; Gross, H. B. and Shibamoto, T. (1996), Analysis of Polar Cholesterol Oxidation Products: Evaluation of a New Method Involving Transesterification Solid Phase Extraction, and Gas Chromatography, J. Agric. Food Chem., 44, 512-517.

Shige, H.; Ishikawa, T.; Suzukawa, M.; Nishiwaki, M.; Yamashita, T.; Nakajima, K.; Ito, T.; Higashi, K.; Ayaori, M.; Yonemura, A.; Nestel, P. and Nakamura, M. (1998), Vitamin E Reduces Cholesterol Esterification and Uptake of Acetylated Low Density Lipoprotein in Macro phages, Lipids, 33 : (12), 11691174.

Smith, L. L. (1987), Cholesterol Autoxidation, Chem. Physis. Lipids, 44, 87.

Teng, J. I.; Kulig, M. J.; Smith, L. L.; Kan, G. and VanLier, J. E. (1973), Sterol Metabolism. XX Cholesterol 7ß-Hydroperoxide, J. Org. Chem., 38, 119.

Vajdi, M. and Nawar, W. W. (1979), Identification of Radiolytic Compounds from Beef, J. Am. Oil Chem. Soc., 56, 611-615.
Received: October 18, 2004; Revised: February 22, 2005; Accepted: December 29, 2005. 